$1-1-1906$

\title{
Poultry experiments : the value of skim milk for egg production : White Leghorns versus mongrels
}

\author{
J. H. Stewart
}

Horace Atwood

Follow this and additional works at: https://researchrepository.wvu.edu/ wv_agricultural_and_forestry_experiment_station_bulletins

\section{Digital Commons Citation}

Stewart, J. H. and Atwood, Horace, "Poultry experiments : the value of skim milk for egg production : White Leghorns versus mongrels" (1906). West Virginia Agricultural and Forestry Experiment Station Bulletins. 102.

https://researchrepository.wvu.edu/wv_agricultural_and_forestry_experiment_station_bulletins/102 




\section{WEST VIRGINIA UNIVERSITY \\ AGRICULTURAL EXPERIMENT STATION \\ MORGANTOWN, W. VA.}

BULLETIN 102.

MAY, 1906.

\section{POULTRY EXPERIMENTS}

The value of Skim Milk for Egg Production.

White Leghorns versus Mongrels.

By J. H. STEWART AND HORACE ATWOOD.

[The Bulletins and Reports of this Station will be mailed free to any citizen of West Virginia upon written application. Address Director of Agricultural Experiment Station, Morgantown, W. Va.] 


\section{THE REGENTS OF THE WEST VIRGINIA UNIVERSITY}

Name of Regent.

P. O. Address.

Hon. C. M. Babb Falls, W. Va.

Hon. J. B. FinleEY ................... Parkersburg, W. Va. Hon. D. C. Gallaher ................. Charleston, W. Va. Hon. E. M. Grant..................... Morgantown, W. Va. Hon. C. E. Haworth ..................Huntington, W. Va. Hon. C. P. MCNeLL.................Wheeling, W. Va. Hon. L. J. Wilimams.................. Lewisburg, W. Va. Hon. T. P. Jacobs.............. New Martinsville, W. Va. Hon. J. R. Trotter.................Buckhannon, W. Va.

President of the Board of Regents............ J. R. TROTTER President of the University................ B. Purinton

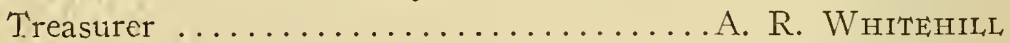

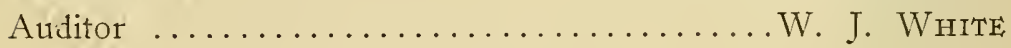

\section{STATION STAFF}

James H. StEwarT, A. M......... Director and Agriculturist Bert H. Hite, M. S............Vice Director and Chemist John L. Sheldon, Ph. D................ Bacteriologist W. E. Rumsey, B. S. Agr........... Entomologist in Charge Horace Atwood, M. S. Agr............ Assistant Agriculturist T. C. Johnson, M. S...............Associate Horticulturist Frank B. Kunst...................... Assistant Chemist C. S. Forkum, B. S.................... Assistant Chemist LEICESTER PATTON..................... Assistant Chemist

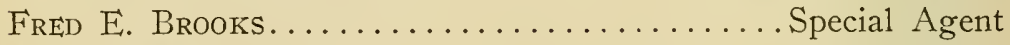
W. J. WhiTE ........................... Bookkeeper

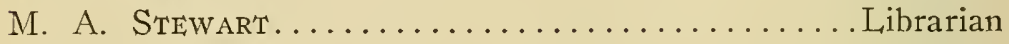

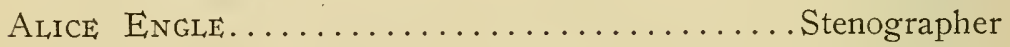




\section{THE VALUE OF SKIM MILK FOR LAYING HENS.}

The experiments described below have been performed to determine the value of skim milk when fed to laying hens. On most farms the skim milk that is produced is fed to calves or pigs. Can fowls use it to better advantage?

Separator skim milk has been used in these experiments. Generally during the colder months of the year is has been sour when fed, and during the warmer periods it has been thick also.

Two experiments have been performed. The first was begun February 29, 1904, and was continued for I22 days. The second test was begun June 30, 1904, and ras continued for three months or until September 3 oth. In the first tests two lots of Single Comb White Leghorn fowls were use, each lot containing 20 hens and two cocks. In the second test each lot of fowls consisted of 60 hens and six cocks.

The fowls were kept in the houses and runs described in former bulletins and the general method of conducting the experiment was the same as that employed heretofore. The skim milk was used for the purpose of moistening the ground feed. This was usually fed in the morning, while the whole grain was scattered in the afternoon in the litter covering the floors of the poultry houses. At no time were the fowls fed heavily as the eggs which were laid were used for hatching and it was not considered desirable to allow the hens to become too fat. It is quite possible that they were not fed as heavily as they might have been for best results during the first experiment as the following table shows that the hens decreased considerably in weight. Pen I refers to the fowls which received the skim milk, while pen 2 refers to the fowls whose mash was moistened with water. 


\section{WEIGHT OF FOWLS.}

\begin{tabular}{|c|c|c|c|c|}
\hline & \multicolumn{2}{|c|}{ Pen 1.} & \multicolumn{2}{|c|}{ Pen 2.} \\
\hline & Hens. & Cocks. & Hens & Cocks. \\
\hline $\begin{array}{l}\text { Average weight at the } \\
\text { beginning of the test. }\end{array}$ & ..3.50 lbs. & $4.25 \mathrm{lbs}$. & 3.62 Ibs. & $4.50 \mathrm{lbs}$ \\
\hline
\end{tabular}

The table shows that the hens in each lot lost in weight about seven-tenths of a pound each, while the cocks gained slightly in weight.

The following table shows the amount and kind of food consumed by each lot of 22 fowls during the I22 days of the test. Both lots of fowls were fed exactly the same except that lot I received in addition 2 quarts of skim milk daily, or 244 quarts during the experiment:

Table showing the amount, kind and cost of the food consumed during the I22 days of the test by each lot of 22 fowls:

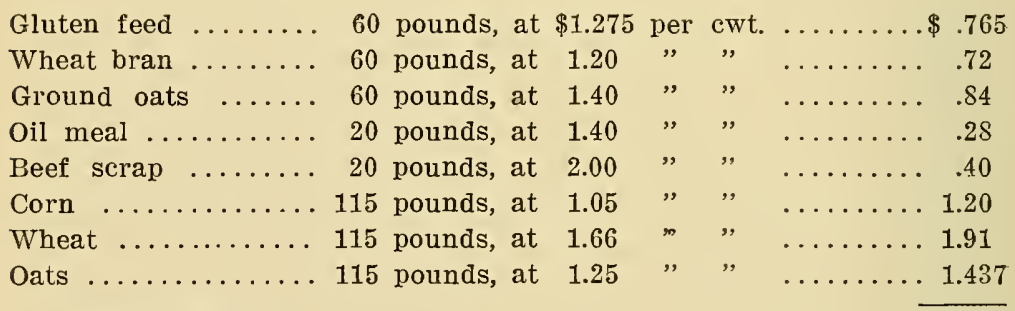

Total cost $\$ 7.752$

If the skim milk be valued at one cent per quart, which is practically equivalent to 50 cents per hundred pounds, an extremely high valuation for feeding purposes, then the total cost of food for pen I was $\$ 10.19$ and for pen $2 \$ 7.75$. 
The following table shows the number of eggs laid by each lot of fowls:

Feb. $29-$ March $31 \ldots \ldots \ldots \ldots \ldots \ldots \ldots \ldots . \ldots 364$

Pen 2

327

Mrarch 31-April $30 \ldots \ldots \ldots \ldots \ldots \ldots \ldots . \ldots 297$

262

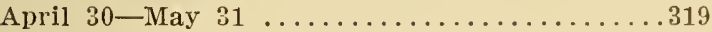

207

May 31-June 29.......................264

200

Total .......................... 1244

The pen which received the skim milk laid 248 eggs more than the other lot of fowls, or practically an extra egg for every quart of skim milk that they received.

Valuing the skim milk at one cent per quart then the food cost of one dozen eggs was 9.8 cents for the fowls fed the skim milk and 9.3 cents per dozen for the other lot of fowls.

During the time covered by the experiment the eggs produced were actually worth 20 cents per dozen. The 248 extra eggs produced by pen I when valued at this price were worth $\$ 4$.I3, which would give to the skim milk a value of 1.6 cents per quart.

\section{SECOND EXPERIMENT.}

In this test six pens of Single Comb White Leghorn fowls were employed, each pen containing 20 hens and 2 cocks. The experiment was divided into two periods, the first beginning June 30, I904, and ending August 5th, the second beginning August 6 th, and ending September 3oth. During the first period pens I, 2 , and 3 each receiving two quarts of skim milk daily which was used to moisten the ground feed as in the earlier experiment, while during the second period pens 4,5 , and 6 received the skim milk.

The following table shows the average weight of the fowls at the beginning and end of the first period: 
AVERAGE WEIGHT OF FOWLS. PERIOD ONE.

\begin{tabular}{|c|c|c|c|c|}
\hline & \multicolumn{2}{|c|}{$\begin{array}{l}\text { BEGINNING } \\
\text { OF PERIOD }\end{array}$} & \multicolumn{2}{|c|}{$\begin{array}{l}\text { END OF } \\
\text { PERIOT }\end{array}$} \\
\hline & Hens & Cocks & Hens & Cocks \\
\hline Pen $1 . \ldots .$. & 2.77 & 4.75 & 2.90 & 4.50 \\
\hline Fen $2 . \quad \ldots \ldots \ldots \ldots \ldots \ldots \ldots \ldots$ & 2.90 & 4.25 & 3.10 & 4.50 \\
\hline Pen $3 . \quad \ldots \ldots \ldots \ldots \ldots$ & 2.72 & 4.75 & 2.80 & 4.75 \\
\hline Average $1,2,3 . \ldots \ldots \ldots \ldots \ldots \ldots$ & 2.79 & 4.58 & 2.93 & 4.58 \\
\hline Pen $4 . \ldots \ldots \ldots \ldots$ & 2.77 & 4.50 & 2.97 & 4.50 \\
\hline Pen 5. . . . . . & 3.05 & 4.25 & 3.25 & 4.25 \\
\hline Pen $6 . \ldots \ldots \ldots$ & 2.90 & 4.50 & 3.07 & 5.00 \\
\hline Average $4,5,6 \ldots \ldots \ldots \ldots \ldots \ldots$ & 2.90 & 4.42 & 3.09 & 4.58 \\
\hline
\end{tabular}

The table shows that all of the hens increased slightly in weight during this period.

The following table shows the amount and kind of food consumed during the first period of 37 days and the cost of the same:

\section{FOOD CONSUMED BY PENS I, 2, AND 3.}

Gluten feed .......54 lbs., at $\$ 1.275$ per cwt.......\$.68s Wheat bran .......54 lbs., at $1.20 \quad "$ " ....... .643

Ground oats ...... 54 lbs., at $1.40 \quad " \quad " \ldots \ldots \ldots . .756$

Beef scrap ....... Is lbs., at $2.00 \quad, \quad " \quad \ldots \ldots \ldots \ldots . .36$ Corn ...........59 lbs., at $1.05 \quad " \quad ", \ldots \ldots \ldots .619$

Wheat $\ldots \ldots \ldots \ldots .59$ lbs., at $1.66 \quad ", \quad " \ldots \ldots \ldots . .979$ Gats .......... 59 lbs., at $1.25 \quad " \quad ", \ldots \ldots \ldots . .737$ 


\section{FOOD CONSUMED BY PENS 4, 5, AND 6.}

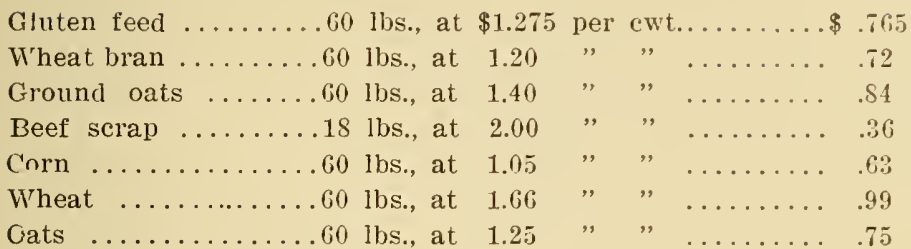

Total cost.

Valuing the skim milk at one cent per quart, which as remarked above is an extremely high valuation for feeding purposes, then the cost of food for pens $\mathrm{I}, 2$, and 3 was $\$ 6.09$ and for pens 4,5 , and $6, \$ 5.05$.

The following table shows the number of eggs laid by each pen of fowls during the 37 days of this period:

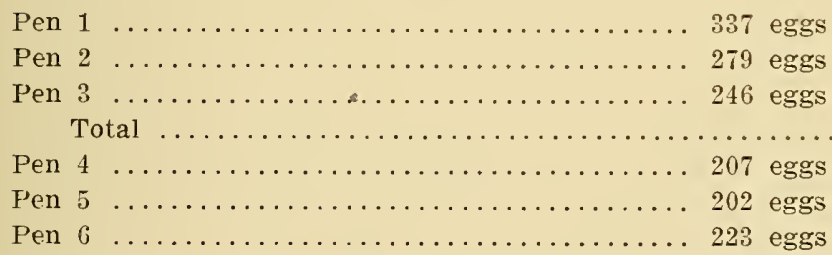

Total 632 eggs

The balance in favor of the milk-fed fowls is $230 \mathrm{eggs}$, which extra egg production was brought about by feeding 222 quarts of skim milk, or slightly more than an extra egg for every quart of skim milk fed.

Valuing the skim milk at one cent per quart then the food cost of the eggs from the milk-fed fowls was 8.4 cents per dozen; and 8.3 cents per dozen for the other lot of fowls.

The eggs produced during this period were worth in the local market 25 cents per dozen. At this price the 230 extra eggs were worth $\$ 4.79$, which would give to the 222 quarts of skim milk an actual feeding value of slightly more than two cents per quart when fed in small quantities as in this experiment. 


\section{PERIOD TWO.}

During the second period of 56 days skim milk was fed to pens 4,5 , and 6 , instead of to pens $I, 2$. and 3 .

The following table shows the average weight of the fowls at the beginning and end of this period.

AVERAGE WEIGHT OF FOWLS. PERIOD TWO.

\begin{tabular}{|c|c|c|c|c|}
\hline & \multicolumn{2}{|c|}{ BEGINNING OF PERIOD } & \multicolumn{2}{|c|}{ END OF PERIOD } \\
\hline & Hens & Cocks & Hens & Cocks \\
\hline Yen $1 \ldots$ & 2.90 & 4.50 & 3.10 & 5.00 \\
\hline Pen $2 \ldots$ & 3.10 & 4.50 & 3.15 & 5.00 \\
\hline Pen $3 \ldots$ & 2.80 & 4.75 & 3.08 & 4.75 \\
\hline Average $1,2,3 . \ldots \ldots \ldots \ldots \ldots \ldots$ & 2.93 & 4.58 & 3.11 & 4.91 \\
\hline Pen $4 \quad \ldots \ldots \ldots \ldots \ldots \ldots \ldots \ldots \ldots \ldots$ & 2.97 & 4.50 & 3.40 & 4.75 \\
\hline Fen $5 \quad \ldots \ldots \ldots \ldots \ldots \ldots \ldots$ & 3.25 & 4.25 & 3.45 & 4.50 \\
\hline Pen $6 \quad \ldots \ldots \ldots \ldots$ & 3.07 & 5.00 & 3.30 & 5.25 \\
\hline Average $4,5,6 . \ldots \ldots$ & 3.09 & 4.58 & 3.38 & 4.83 \\
\hline
\end{tabular}

During this period the hens which received the skim milk increased in weight slightly more than those whose mash was moistened with water.

The following table shows the kind, amount and cost of the food consumed during this period:

\section{FOOD CONSUMED BY PENS I, 2, AND 3.}

Corn meal ........105 lbs., at $\$ 1.25$ per cwt. ......\$1.31

Wheat bran ...... 105 lbs., at $1.20 "$ " $\ldots \ldots \ldots .1 .26$

Ground oats ...... 105 lbs., at $1.40 \quad " \quad " \ldots \ldots \ldots .1 .47$

Beef scrap ....... 33 lbs., at $2.00 \quad " \quad$ " ....... .66

Corn .......... 180 lbs., at $1.05 \quad " \quad$ " $\ldots \ldots \ldots 1.89$

Oats ........... $180 \mathrm{lbs}$, at $1.25 \quad " \quad " \ldots \ldots \ldots 2.25$

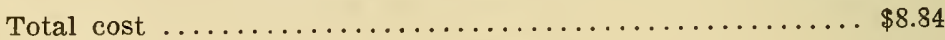


FOOD CONSUMED BY PENS 4, 5, AND 6.

Corn meal

101 lbs., at $\$ 1.25$ per cwt.

$\$ 1.262$

Wheat bran

101 lbs., at 1.20

1.212

Ground oats

101 lbs., at 1.40

1.414

Beef scrap ....... 33 lbs., at 2.00

Corn

149 lbs., at 1.05

1.564

Oats ........... 149 lbs., at 1.25

Total cost

$\$ 7.74$

Valuing the six quarts of skim milk which were fed daily to pens 4,5 , and 6 at one cent per quart then the total cost of food for these pens was $\$$ Ir.ro and for the other fowls $\$ 8.84$.

The following table shows the number of eggs laid by each pen of fowls during the second period:

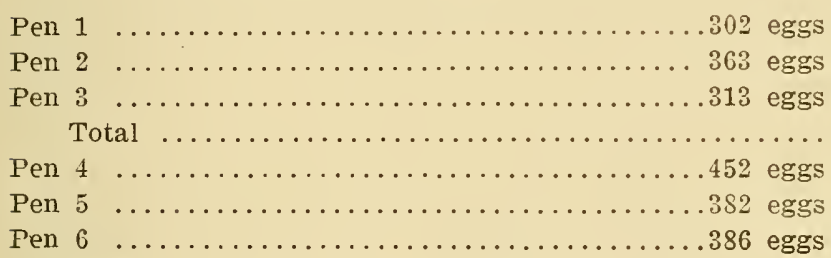

Total

978 eggs

During this period there were fed 336 quarts of skim. milk which increased the egg production 242 eggs, or at the rate of three-fourths of an egg for every quart of skim milk fed. The eggs produced during this period were worth 25 cents per dozen in the local market. Valuing the 242 extra eggs at this price it is seen that the skim milk had a feeding value in this case of one and one-half cents per quart.

\section{SUMMARY.}

In both experiments more eggs were produced when skim milk was substituted for water for moistening the mash.

Under the conditions prevailing in these experiments and with eggs selling for twenty or twenty-five cents per dozen the skim milk used for moistening the mash had a feeding value of from one and one-half to two cents per quart.

In these trials 802 quarts of skim milk were fed, resulting in an increase in the egg production of 702 eggs. 


\section{WHITE LEGHORNS COMPARED WITH MONGRELS FOR EGG PRODUCTION.}

During the winter months fresh eggs are very high in price and difficult to procure, and the question arises is this condition of the egg market due to the fact that the common fowls of the country are poor winter layers, or is it due to their being poorly housed and insufficiently fed?

In order to throw some light on this subject and also to determine whether White Leghorns or mongrels are more profitable as egg producers the experiment described below has been performed.

In the summer of IgO4 fifty young pullets, which were typical of the cummon mixed stock of the country, were bought from farmers living in the vicinity of Morgantown. A few of them showed traces of Barred Plymouth Rock and Light Brahma blood. Two or three resembled Barred Plymouth Rocks in color but were provided with a crest, and the rest of them were of various colors. They were allowed to run at large until fall. Then they were divided into two lots and placed in the laying houses provided for them. (For a description of these houses see bulletin No. 7r.) Fifty Single Comb White Leghorn pullets of approximately the same age as the mongrels were selected and placed in two similar houses.

The experiment began November I4, I904, and this report gives the results for the first year of the test. The general plan of conducting the experiment was as follows: The feed was carefully weighed for each lot and placed in covered boxes in the houses. The actual feeding of the forvls was entrusted to a little colored boy, who, it is believed, gave the fowls at least as. careful attention as they would have received on the average farm. He was instructed to feed only what the fowls seemed to require, but as he was naturally a liberal feeder it is probable that a portion of the time the fowls were somewhat too fat for best results. They were fed whole grain scattered in litter in the morning and a mash at night, The whole grain consisted of equal parts by weight of corn and oats. No wheat was fed owing to 
its high price. The ground feed consisted principally of corn meal, ground oats, and wheat middlings to which was added about ten per cent. of beef meal. During the first eleven months of the year the ground grain was moistened with skim milk, the rest of the time with water.

The average weight of the mongrels at the beginning of the test was $3.4 \mathrm{I}$ pounds, and at the end of the first year $4.6 \mathrm{I}$ pounds, while the Leghorns weighed 3.14 pounds at the beginning and 3.35 pounds at the end of the test. Consequently the mongrels gained considerably more in weight than the Leghorns.

The following table shows the kind, amount and cost of food consumed, per head, by the mongrels and Leghorns during the year:

MONGRELS

Corn meal at $\$ 1.25$ per cwt. 7.3 lbs....\$ .091

Wheat bran " 1.20 " " $1.7 \mathrm{lbs} . . . . \quad .020$

Cround oats " $1.40 \quad$ " " 6.5 lbs.... .091

Gluten feed " $1.275 "$ " $\quad 3.4$ lbs.... . .043

Beef meal " 1.80 " " 3.9 lbs.... .070

Middlings " $1.20 \quad$ " " $5.6 \mathrm{lbs} . \ldots . .067$

Corn " $1.05 \quad " \quad$ " 19.8 lbs....

Oats " 1.25 " " $18.6 \mathrm{lbs} . \ldots . .232$

Milk " $.005 "$ quart 20 quarts. .100
WHITE LEGHORNS

7.2 lbs....\$ .090

1.6 lbs.... .019

$6.4 \mathrm{lbs} . \ldots . \quad .089$

3.4 lbs.... .043

3.8 lbs.... .068

$5.6 \mathrm{lbs} . . . .067$

17.1 lbs..... .179

15.9 lbs..... . .198

20 quarts. .100

Total cost ............................. .821

The total amount of food consumed by the mongrels per head, without taking into consideration the skim milk, was 66.8 pounds, and for the Leghorns 6I pounds, and the total cost of food at the prices given in the table was $\$ 0.92 \mathrm{I}$ and $\$ 0.853$ for the mongrels and Leghorns respectively.

The following table shows the number of eggs produced by each lot of fowls for each month of the year, together with their value calculated according to local retail prices: 


\begin{tabular}{|c|c|c|c|c|c|}
\hline \multirow{2}{*}{ MONTH } & \multirow{2}{*}{$\begin{array}{c}\text { Frice per } \\
\text { dozen. } \\
\text { Cents. }\end{array}$} & \multicolumn{2}{|c|}{ MONGRELS } & \multicolumn{2}{|c|}{ LEGHORNS } \\
\hline & & $\begin{array}{l}\text { No. eggs } \\
\text { laid }\end{array}$ & Value & $\begin{array}{l}\text { No.eggs } \\
\text { laid }\end{array}$ & Value \\
\hline $\begin{array}{r}1904 \\
1904\end{array}$ & & & (c) $\quad 150$ & 165 & 4125 \\
\hline December . & 35 & 39 & 1.137 & 269 & 7.846 \\
\hline January $\ldots \ldots \ldots$ & 35 & 149 & 4.346 & 260 & 7.583 \\
\hline February ......... & 30 & 170 & 4.250 & 335 & 8.375 \\
\hline March ........... & 20 & 761 & 12.683 & 919 & 15.316 \\
\hline April .... . & 20 & 820 & 13.666 & 858 & 14.300 \\
\hline May ........... & 20 & 598 & 9.966 & 733 & 12.216 \\
\hline June ............ & 20 & 521 & 8.683 & 563 & 9.383 \\
\hline July ........... & 20 & 505 & 8.416 & 574 & 9.566 \\
\hline August $\ldots \ldots \ldots$.... & 23 & 425 & 8.146 & 421 & 8.069 \\
\hline September ........ & 24 & 447 & 8.940 & 452 & 9.040 \\
\hline October .......... & 28 & 283 & 6.608 & 248 & 5.786 \\
\hline November 14 th ..... & 30 & 83 & 2.075 & 27 & .675 \\
\hline Total $\ldots \ldots \ldots$ & & 4,807 & 89,061 & 5,824 & 112,280 \\
\hline Average per hen.... & & 96.1 & 1.78 & 116.5 & 2.24 \\
\hline
\end{tabular}

The mongrels produced eggs to the value of $\$ 1.78$ and the Leghorns to the value of $\$ 2.24$. If we deduct, in each case, the cost of food from the value of the eggs there remain balances of \$o.86 and \$r.39 for the mongrels and Leghorns respectively. If we take into consideration only the cost of the food consumed and the value of the eggs produced then the Leghorns gave 53 cents per head more profit than the mongrels. The mongrels gained in weight one pound per head more than the Leghorns. Valuing this at $I 3$ cents per pound then the Leghorns gave 40 cents more net profit per hen than the mongrels. 


\section{SUMMARY.}

I. Fifty White Leghorns were compared with fifty mongrels for one year as to cost of food and egg production, ordinary care and attention being given them such as they would receive on the average farm.

2. In addition to skim milk used to moisten the mash the Leghorns consumed 6 I pounds of food costing 85.3 cents, and the mongrels consumed 66.8 pounds of the same materials costing 92. I cents.

3. During the year the Leghorns laid II6.5 eggs worth $\$ 2.24$ per hen, and the mongrels 96. I eggs worth $\$ 1.78$ per hen.

4. The Leghorns gave a profit over the cost of food of \$I.39 and the mongrels a profit of 86 cents.

5. The mongrels gained in weight one pound per head more than the Leghorns. If this increase in weight is taken into consideration then the Leghorns gave a profit of 40 cents per hen more than the mongrels.

6. The highest prices for fresh eggs usually prevail during the months of November, December, January and February. During these four months the mongrels laid only 364 eggs and the Leghorns 1029 or practically three times as many.

\section{THE ERROR INCIDENT TO EXPERIMEN'TS CONCERN- ING EGG PRODUCTION.}

In conducting poultry experiments, or in fact experiments of any kind, it is important to know how nearly duplicate results can be obtained when the conditions are all as nearly the same as it is possible to obtain them. For example, when one wishes to compare the value of two foods say beef scrap and ground fresh meat and bone for egg production, one of these materials is added to the ration for one lot of fowls and the other material is added to the ration for another similar lot of fowls and the observed difference in the egg production of the two lots of fowls is 
attributed to a difference in the food value of the two feeding stuffs under consideration. In such a case as the one just mentioned the assumption must necessarily be made that the egg production of the two lots of fowls would have been identical provided that both lots of fowls had been fed alike. But are we justified in assuming that this is true, for we know that the normal production of eggs in different individuals even of the same breed differs considerably.

In the test of White Leghorns versus mongrels opportunity was given to study this matter. The two flocks of Leghorns were composed of pullets of the same breed, of the same age, and practically of the same weight, and they were fed on the same foods, and as nearly as possible the same amount.

The following table shows the average weight of the fowls at the begnining and at the end of the test, and the amount of food consumed by each lot of 25 fowls during the year:

Average weight Average weight

Pounds food at beginning. at end. consumed.

\begin{tabular}{lrrrr}
\hline Lot 1. & $\ldots \ldots \ldots \ldots \ldots \ldots .08$ & 3.30 & 1,522 \\
\hline Lot 2. & $\ldots \ldots \ldots \ldots \ldots \ldots \ldots 3.20$ & 3.40 & 1,538
\end{tabular}

The following table shows the egg production by months for the year. The second and fourth columns give the total number of eggs produced at the end of each calendar month and at the end of the test. The fifth column gives the difference between these totals and the sixth column shows the percentage variation in the egg production of the two lots of fowls based in each case upon the lower egg yield: 


\begin{tabular}{|c|c|c|c|c|c|c|}
\hline & Lot 1 & Totals & Lot 2 & Totals & $\begin{array}{l}\text { Differ- } \\
\text { ence }\end{array}$ & $\begin{array}{l}\text { Variation } \\
\text { per cent. }\end{array}$ \\
\hline November 14 th. ... & 77 & 77 & SS & 88 & 11 & 14.2 \\
\hline $\begin{array}{c}\text { December } \ldots \ldots \ldots \\
1905 .\end{array}$ & 130 & 207 & 139 & 227 & 20 & 9.6 \\
\hline January $\quad . . \ldots \ldots$ & 116 & 323 & 144 & 371 & 48 & 14.8 \\
\hline February ......... & 187 & 510 & 148 & 519 & 9 & 1.7 \\
\hline March $\ldots .$. & 458 & 968 & 461 & 980 & 12 & 1.2 \\
\hline April $\ldots \ldots \ldots \ldots$ & 416 & 1,384 & 442 & 1,422 & 38 & 2.7 \\
\hline Miay $\ldots \ldots \ldots \ldots$ & 373 & 1,757 & 360 & 1,782 & 25 & 1.4 \\
\hline Jane $\ldots \ldots \ldots \ldots$ & 275 & 2,032 & 288 & 2,070 & 38 & 1.8 \\
\hline July ........ & 279 & 2,311 & 295 & 2,365 & 54 & 2.3 \\
\hline August $\ldots . .$. & 228 & 2,539 & 193 & 2,558 & 19 & .7 \\
\hline September . . & 239 & 2,778 & 213 & 2,771 & 7 & .25 \\
\hline October $\quad \ldots \ldots \ldots$ & 105 & 2,883 & 143 & 2,914 & 31 & 1.07 \\
\hline November 14 th. ... & 18 & 2,901 & 9 & 2,923 & 22 & .75 \\
\hline Total for the year.. & 2,901 & & 2,923 & & 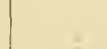 & \\
\hline
\end{tabular}

The table shows that after the test had been running three and one-half months the variation in the egg yield dropped down to I.7 per cent., and that at no time thereafter was the variation larger than 2.7 per cent.

These results indicate that in poultry experiments of this class in which twenty-five or more fowls are used in each lot the results of a six months trial will be practically as accurate and reliable as though the test were continued for an entire year. Also that the error, almost inseparably connected with experiments of this nature should not exceed three per cent. after the test has been conducted for four or five months. 
